\title{
Sangria: palavra de corte de Luiza Romão
}

\section{SANGRIA: CUT WORD OF LUIZA ROMÃo}

Bruna Escaleira ${ }^{1}$

DOI: 10.11606/issn.1981-7169.crioula.2017.140450

omeça com um close: uma vulva em alta definição. A vagina censurada. Ou melhor, rasurada. Sobre a foto em preto e branco que estampa a capa de Sangria, um emaranhado de linha vermelha junta lâminas de estilete, formando um asterisco sobre a fissura genital. Em vez de esconder a imagem proibida, o signo de censura reflete as marcas do sistema capitalista patriarcal sobre o corpo da muIher: a violência, a mutilação, o silenciamento. $O$ trabalho visual estende-se em ilustrações por todo o livro e reforça uma poética que se dá nas quebras dos corpos e dos discursos, produzindo rasuras nos limites intransponíveis pela palavra, experimentando formas de gritar:

eu queria escrever a palavra $\mathrm{br}^{*}+\wedge \%$

a palavra $\mathrm{br}^{*}+\wedge \%$ queria escrever eu palavra eu $\mathrm{br}^{*}+\wedge \%$ escrever queria BRASIL

eu queria escrever a palavra brasil

(ROMÃO, 2017, p. 17)

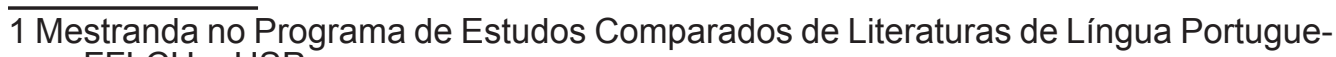
sa - FFLCH - USP. 
Desde a primeira estrofe, a dificuldade de dizer é forma e conteúdo de uma escrita que gagueja, esbarra, precisa a todo momento transpor os limites da linguagem para se fazer ouvir. Contra qualquer obstáculo, essa voz está decidida a concluir seu objetivo e usa todos os recursos disponíveis para fazê-lo, seja pela aproximação de elementos extratextuais ao conteúdo - as fotografias com intervenções de bordados e aplicações de peças metálicas feitas artesanalmente pela autora permeiam toda a publicação -, seja por meio do próprio texto, usando sinais gráficos que simulam a impossibilidade de fala, como em "br* ${ }^{\star} \%$ " (Ibidem), ou a escrita em letras maiúsculas de "BRASIL" (Ibid.), que salta aos olhos como um grito aos ouvidos.

De fato, a escrita de Luiza Romão não é feita para permanecer muda sobre o papel. A oralidade é marca constante na obra da jovem paulista de Ribeirão Preto, que migrou da atuação teatral para a poética por meio da cena dos saraus, slams e batalhas de rima nas periferias paulistanas. Depois de ganhar o Slam do 13, o Slam da Guilhermina e tornar-se vice-campeã nacional do Slam BR em 2013, a então estudante de Artes Cênicas reuniu seus versos em Coquetel Motolove (Selo Do Burro, 2014), seu livro de estreia. Para disseminar sua produção, passou a lançar videopoemas nas redes sociais, explorando a linguagem do spoken word.

Sempre ligada a movimentos sociais, é quase impossível separar as criações de Luiza de seu posicionamento político. $O$ tom de denúncia e reivindicação é uma constante em sua obra que ganhou mais elaboração em Sangria. Em seu segundo livro, o fluxo criativo foi canalizado para dar conta de um tema 
específico, como contou a autora em uma entrevista para minha coluna na Revista Azmina, por ocasião do lançamento:

Eu terminei o primeiro rascunho do Sangria em novembro/dezembro de 2015 (acho). Nessa época, eu entendi que queria falar sobre mulher. Tudo o que eu escrevia passava pelo 'universo feminino' (cultura do estupro, afetividade, assédio, etc.). Era uma questão que eu precisava elaborar (em mim e no papel). Além disso, comecei a perceber que toda minha produção esbarrava numa perspectiva histórica, uma compreensão estrutural da coisa. Repara quantas vezes eu falo 'país', 'história', 'corpo', 'Brasil' num poema. Inúmeras. Aí saquei. Esse era o recorte. Por que não revisitar nossa história pela perspectiva de um útero, compreender como os papéis femininos foram construídos através dos séculos, como as raízes do patriarcado estão 'laaaá' no 'começo de tudo'? Aí veio a Sangria. Passei os últimos anos, escrevendo, reescrevendo, pesquisando essa lógica do ciclo menstrual, como afiar a palavra até ela se tornar uma lança. ${ }^{2}$

Para "escavar" e expor as estruturas machistas que sustentam as ideias dominantes de "Brasil", a poeta constrói uma linha narrativa que liga um poema ao outro e leva o leitor numa espécie de "epopeia", misturando as fases da criação nacional aos períodos do ciclo menstrual. Esse arranjo concatenado combina com as frequentes referências a mitos clássicos e com o tom épico de boa parte dos versos, o que pode suge-

2 ESCALEIRA, Bruna. Poeta mostra a história do Brasil sob a ótica de um útero. Revista Azmina. 26/09/2017. Disponível em: http://azmina.com.br/2017/09/poeta-mostra-a-historia-do-brasil-sob-a-otica-de-um-utero/ 
rir a leitura da enunciadora como uma heroína feminista que cumpre seu ciclo de luta contra o patriarcado - sempre pronto a recomeçar. Partindo das opressões mais estruturais representadas nos capítulos iniciais (1 - Genealogia e 2-Descobrimento), a enunciadora vai esmiuçando as violências cotidianas da vida íntima das mulheres nos capítulos seguintes: 3 - Tensão pré-menstrual, 4 - Corte (que fala da interrupção da gestação por pílulas do dia seguinte), 5 - Ovulação e 6-Menstruação.

Apesar da evolução do tema e da ligação de um capitulo ao outro, o livro é todo entrecortado. Tudo nele parece lembrar os cortes, as fissuras sociais que motivaram sua escrita: as intervenções vermelhas nas fotografias em preto e branco, a organização gráfica que intercala páginas de texto às estampadas por imagem ou às páginas vermelhas que anunciam cada capítulo, até a diversa composição dos poemas - alguns correm como diálogos por algumas páginas, outros ocupam poucas linhas e há, ainda, poemas diagramados em parágrafos contínuos como prosa. Mais que isso, as quebras se dão no discurso que passa, a todo momento, de aspectos íntimos do corpo feminino, como a menstruação, a episódios históricos e políticos:

um país nasceu

não de parto

nem de partida

mas de chegada

enviado da corte

fruto de cortes

fundos na pele

sempre "mestiça"

(ROMÃO, 2017, p. 21) 
É como se a poeta quisesse dizer que o ciclo menstrual das mulheres - representado dia-a-dia pelos 28 poemas que compõe o livro diagramado em forma de calendário e sem numeração de páginas - é a todo momento impedido de realizar-se na sua fluidez natural pelo machismo que corrói os alicerces de todas as estruturas sociais. Da mesma forma, os discursos dos corpos marcados pela diferença esbarram sempre nas estruturas de poder que formam a linguagem e, por isso, constroem-se de maneira descontínua, nas rasuras, nos limites da palavra e dos gêneros canônicos.

É justamente nos limites entre as artes que Luiza encontra sua forma de expressão. Formada em Direção Teatral pela Universidade de São Paulo (USP) e em interpretação na Escola de Artes Dramáticas (EAD), a autora costuma transcender gêneros e linguagens em seus projetos. Foi assim que Sangria, tornou-se também uma série de videoperformance. Romão passou a diretora e convidou 28 mulheres de diferentes áreas artísticas (como grafite, pintura, xilogravura, circo, dança, tecido acrobático, teatro de bonecos, bordado, teatro, intervenção urbana, linguagem de sinais e música) para participar: cada uma delas escolheu um dos 28 poemas do livro e propôs uma performance. Essas intervenções foram filmadas e os poemas gravados e musicados pelo duo de baixo acústico, por Vânia Ornelas, e percussão, por Juba Carvalho.

Toda essa produção foi apresentada no show-lançamento do livro, realizado em 11 de outubro de 2017 no Sesc Pinheiros, e deve seguir encontrando-se com o público em apresentações esporádicas que a autora busca oferecer, sempre que pode, com apoio de centro culturais, movimentos sociais ou 
por conta própria. De toda forma, qualquer uma dessas apresentações, leituras dramáticas, viedeopoemas ou o próprio livro são apenas recortes, facetas desse corte profundo que a poeta promove em suas entranhas para transformar em arte sua sangria.

ROMÃO, Luiza Sousa. Sangria. São Paulo: Edição do Autor: Selo do Burro, 2017.

Submissão: 07/11/2017

Aceite: $07 / 11 / 2017$ 